\title{
Occurrence of faecal endoparasites in reindeer (Rangifer tarandus) in two grazing areas in northern Norway
}

Lene Idland ${ }^{1}$, Amalie Moen Juul ${ }^{1}$, Ellen Karin Solevåg ${ }^{1}$, Kristoffer Relling Tysnes ${ }^{1}$, Lucy Jane Robertson ${ }^{1}$ and Kjersti Selstad Utaaker ${ }^{1,2^{*}}$

\begin{abstract}
Background: Semi-domesticated reindeer represent an important livestock industry and livelihood for a proportion of the human population in northern Fennoscandia. Reindeer husbandry is considered an extensive animal husbandry, where the animals are kept mostly on natural pastures, although sometimes kept in fenced areas for shorter periods. These reindeer may harbour a variety of parasites that may affect animal health and production. The relatively limited close contact between herds and owners gives limited opportunities for diagnosis and treatment of diseases in general. Furthermore, the effects of subclinical parasitism in livestock are commonly expressed as a reduction in productivity rather than clinical disease and mortality. Thus, specific knowledge of endoparasites and parasitic infections in these herds is scarce. This study investigated the occurrence of various endoparasites in reindeer by analysis of a total of 114 faecal samples from winter-slaughtered reindeer from two different grazing areas in Troms and Finnmark, Norway.
\end{abstract}

Results: Using a McMaster method, a Baermann technique, and a direct immunofluorescent antibody test, the following parasites were identified in the faecal samples with the occurrence data given as percentages: Strongylid eggs (62\%), Nematodirinae spp. eggs (24\%), Capillaria sp. eggs (42\%) and Moniezia spp. eggs (17\%), Dictyocaulus spp. larvae (14\%) protostrongylid larvae (40\%), Eimera spp. oocysts (23\%), and Giardia duodenalis cysts (5\%). Cryptosporidium oocysts were not detected. Parasite eggs, oocysts, and cysts were quantified.

Molecular analysis revealed G. duodenalis sub-assemblage Al, a potentially zoonotic genotype not previously reported in reindeer from this region. Morphological analyses of Eimeria oocysts identified two species, Eimeria mayeri and Eimeria rangiferis, and molecular analyses of the cytochrome C oxidase I (coi) gene and 18 s rRNA (18SSU) gene of Eimeria confirmed the presence of Eimeria species that are specific to reindeer.

Conclusions: A high prevalence, but low burden, of endoparasites was detected in samples from these semi-domesticated reindeer. The samples were collected during winter, when adult gastrointestinal parasites usually produce only low numbers of transmission stages. Therefore, together with the low number of samples, detailed and definitive conclusions regarding parasite status of semi-domesticated reindeer are avoided. Nevertheless, these data provide

\footnotetext{
${ }^{*}$ Correspondence: kjersti.s.utaaker@nord.no

${ }^{1}$ Parasitology Laboratory, Department of Paraclinical Sciences, Faculty

of Veterinary Medicine, Norwegian University of Life Sciences, Adamstuen

Campus, Sentrum, PO Box 369, Oslo 0102, Norway

Full list of author information is available at the end of the article
}

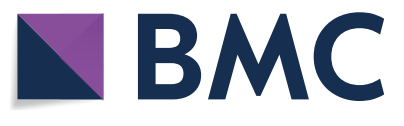

(c) The Author(s) 2021. This article is licensed under a Creative Commons Attribution 4.0 International License, which permits use, sharing, adaptation, distribution and reproduction in any medium or format, as long as you give appropriate credit to the original author(s) and the source, provide a link to the Creative Commons licence, and indicate if changes were made. The images or other third party material in this article are included in the article's Creative Commons licence, unless indicated otherwise in a credit line to the material. If material is not included in the article's Creative Commons licence and your intended use is not permitted by statutory regulation or exceeds the permitted use, you will need to obtain permission directly from the copyright holder. To view a copy of this licence, visit http://creativeco mmons.org/licenses/by/4.0/. The Creative Commons Public Domain Dedication waiver (http://creativecommons.org/publicdomain/ zero/1.0/) applies to the data made available in this article, unless otherwise stated in a credit line to the data. 
a snapshot overview of parasite occurrence in a semi-domesticated animal group vulnerable to the various environmental changes to which they are exposed.

Keywords: Capillaria, Dictyocaulus, Eimeria, Giardia, Moniezia, Nematodirinae, Protostrongylid, Rangifer tarandus, Strongylid

\section{Background}

Reindeer herding in Fennoscandia can be traced back to the $1500-1600 \mathrm{~s}$. Although this animal husbandry has undergone vast transformations, the most dramatic changes have probably occurred during the last few decades through modernisation of herding by new technology, larger and commercial slaughterhouses, and the commercialisation of reindeer products.

In the Saami reindeer husbandry in Norway, the pasture areas extend from the counties Troms og Finnmark to Innlandet [1]. Around $40 \%$ of Norway's total mainland area is reindeer pasture [2] and constitutes roughly $140,000 \mathrm{~km}^{2}$.

The reindeer grazing areas are divided into 6 regional ranges, further divided into 82 grazing districts. In each district, groups of reindeer owners share responsibilities such as herding. These herd groups are called siida or sitje [3].

Troms og Finnmark is the northernmost county in Norway and has the highest number of semi-domesticated reindeer. The number of semi-domesticated reindeer in the Finnmark area in March 2018 was 146,900, which constituted about $70 \%$ of the total number of reindeer in Norway. Trendwise, the total number of semi-domesticated reindeer in Norway has decreased by $8 \%$ since 2014 , mainly due to increased culling [4].

Reindeer are herd animals grazing freely on pastures, which may be shared with other animals and reindeer belonging to more than one owner. Although these pastures constitute large areas of Finnmark county $(55,000$ $\mathrm{km}^{2}$ ) where the animals can roam freely, there is a theoretical risk of pathogen transmission between herds. This may be associated with feeding, activities such as reindeer racing, outfield industry (hunting, tourism, and international military activity), and trade and transport of live reindeer.

Reindeer mainly graze on natural pastures throughout the year, continuously exposed to environmental challenges (e.g., weather, climate, landscape alterations, and predators).

Although traditionally not considered to represent a challenge to reindeer husbandry, gastrointestinal parasite prevalence and intensity could be expected to increase in the future due to warmer and wetter climates and reductions of areas available for grazing. A large epidemiological study of gastrointestinal parasites in semi-domesticated reindeer calves from Fennoscandia included samples from an area in northern Norway, and the authors highlighted "detailed baseline information about parasitic infections is limited" [5].

The aim of this study was to investigate the occurrence of endoparasites in reindeer from two grazing districts in Troms and Finnmark, Norway, and supply data regarding endoparasite occurrence.

\section{Methods}

\section{Study area and sample collection}

In October 2017 and January 2018, a total of 114 faecal samples were collected from semi-domesticated reindeer from two different grazing districts in Troms and Finnmark, Norway (Fig. 1a.). Of these, fecal samples from 46 reindeer belonging to the Spierttagáisá district close to Karasjok, although grazed in Porsanger municipality during the summer, and fecal samples from 68 reindeer grazed at Neiden, an area in Sør-Varanger (Fig. 1b). Both areas include sheep pastures, with a relatively low density and number of sheep [6], some cattle farms, and the natural pasture is also shared with an increasing moose population [7]. All samples were collected at the slaughterhouse either in Karasjok or in Kautokeino.

The samples were selected by convenience, and were collected at the slaughterhouse. From both districts, samples were collected from the rectum directly into numbered sample containers along the slaughter line at the station where the intestinal organs were removed. A minimum of $10 \mathrm{~g}$ faeces from each animal was collected. The samples from Spierttagáisá were shipped overnight to the laboratory with a cooler, whereas samples from Neiden were cooled outside in the snow (air temperature between -15 and $-30{ }^{\circ} \mathrm{C}$ ) for 5 days before overnight transportation to the laboratory in a cool bag. Whether the samples froze during storage in Neiden is unknown. All samples were stored at $4{ }^{\circ} \mathrm{C}$ before analysis at the Parasitology Laboratory, Oslo, Norwegian University of Life Sciences (NMBU), and were analysed within 7 days after arrival.

The animals from Spierttagáisá had not received any antihelminthic treatment. Treatment status were unknown regarding the animals from Neiden. In addition to collecting faecal samples, the age group of animals sampled were recorded. All the information was included in a Microsoft Excel database. 

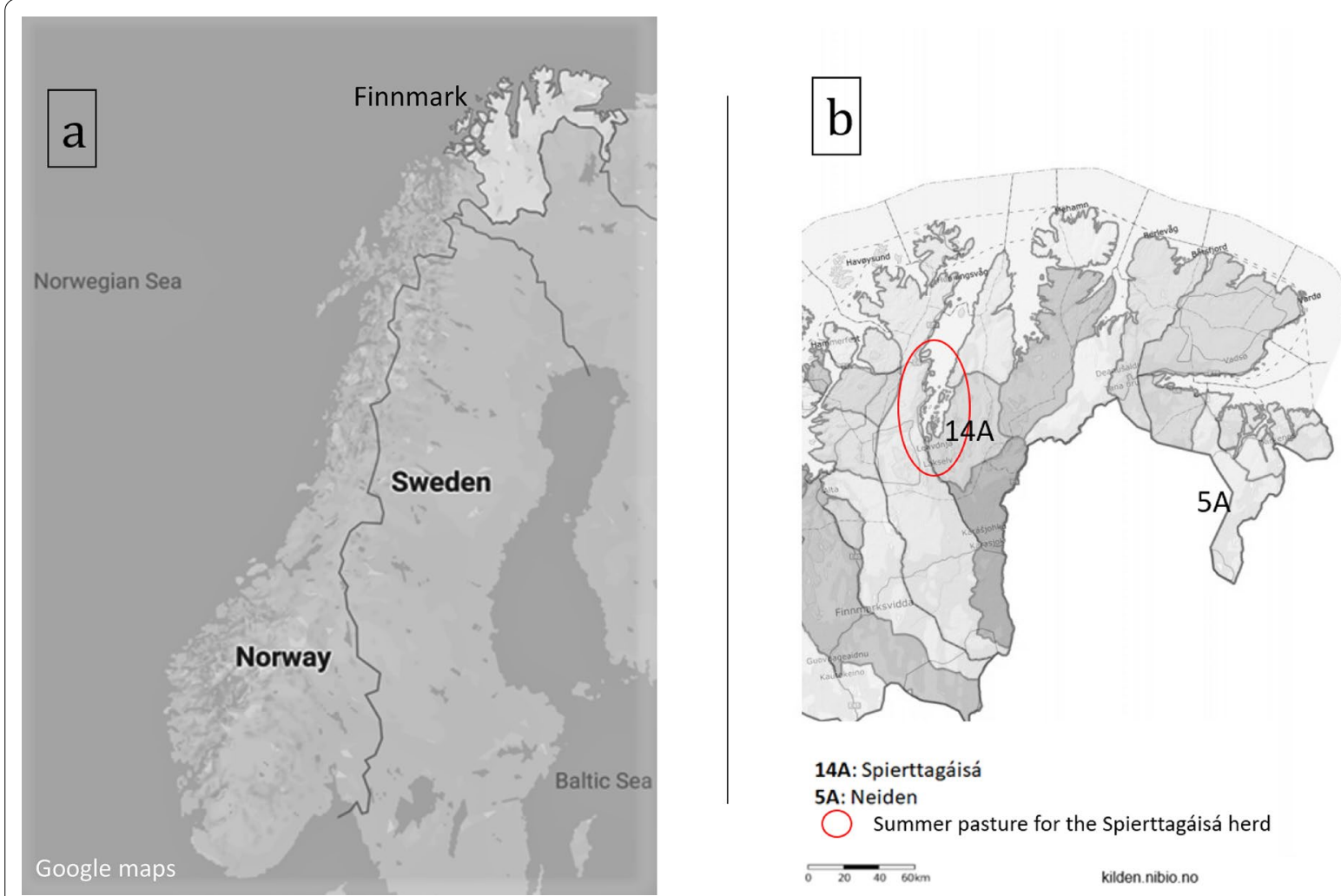

Fig. 1 Map of Fennoscandia (a) and Finnmark (Troms and Finnmark County, Norway) with grazing areas of reindeer herds sampled and investigated for parasites (b)

\section{Parasitological procedures Modified McMaster flotation test}

Faeces $(3 \mathrm{~g})$ were homogenized with $57 \mathrm{~mL}$ water in a mechanical blender. The suspension was then poured through a metal sieve with a pore diameter of $250 \mu \mathrm{m}$ for concentration, and divided into two $10 \mathrm{~mL}$ tubes, and centrifuged at $1,510 \times g$ for $3 \mathrm{~min}$. Supernatants were discarded after centrifugation. Sediment from one test tube was resuspended with a saturated $\mathrm{NaCl}$ solution (specific gravity $1.18-1.20 \mathrm{~g}$ ) using a vortex-mixer, and $2 \mathrm{~mL}$ of this suspension was transferred to a McMaster counting chamber (Whitlock Universal, Australia). The whole slide was examined at $40 \times$ and $100 \times$ magnification for detection and quantification of helminth eggs and Eimeria oocysts.

\section{Baermann technique}

The Baermann technique was used to collect larvae from faecal material for subsequent identification [8]. In brief, approximately $5 \mathrm{~g}$ of faeces were wrapped in gauze and placed in a funnel connected to a closed tube. The funnel was filled with tepid water and left overnight. Fluid from the stem of the tube was then transferred to $10 \mathrm{~mL}$ pointed centrifuge tubes and centrifuged for $5 \mathrm{~min}$ at
$1,510 \times g$. The supernatant was carefully removed until approximately $1 \mathrm{~mL}$ was left in the tube, which was examined by microscopy at $\times 40$ and $\times 10$ magnification to identify Dictyocaulus spp. and protostrongylid larvae based on morphology. For some samples, a drop of iodine was used to fix and colour the larvae for easier identification. Larvae were not quantified.

\section{Isolation of Eimeria oocysts}

An in-lab protocol was used for isolation of Eimeria spp. oocysts from positive samples. Attempts were made to isolate from those samples containing $>600$ oocysts per gram faeces (a total of nine samples from Neiden and six samples from Spierttagáisá). In brief, faeces were washed in several steps, followed by flotation using $33 \% \mathrm{ZnSO}_{4}$ solution. Oocysts were collected into $2 \mathrm{~mL}$ centrifuge tubes. The isolated oocysts were incubated for about two weeks at room temperature (approximately $22{ }^{\circ} \mathrm{C}$ ) before being examined for sporulation by microscopy; for this, $10 \mu \mathrm{L}$ of oocyst suspension was placed on a slide and covered by a coverslip. The slide was examined under $\times 200$ and $\times 1000$ magnification, and structures were measured using the Las X software (Leica Microsystems GmbH, Germany). 


\section{Species identification of Eimeria by morphology}

To identify the Eimeria species, the size and morphology of the isolated oocysts and the sporocysts within were examined by microscopy. Nomarski (differential interference contrast) optics on the same microscope were used to examine morphology, and morphological features (e.g., micropyle, operculum etc.) recorded. An eyepiece graticule and camera imaging system were used to measure the size (length $\mathrm{x}$ width) of 20 Eimeria oocysts per sample (or fewer if fewer were found), and, for 10 of these oocysts, the size of the sporocyst was also measured. The morphological features were compared with those of other Eimeria species for which details have previously been published [9].

\section{Immunofluorescent antibody test (IFAT)}

An immunofluorescence antibody test (IFAT) was used to analyse for the presence of Giardia spp. cysts and Cryptosporidium spp. oocysts on direct faecal smears. Between 5 and $20 \mu \mathrm{L}$ of homogenized and sieved material was placed on a microscope slide using a plastic bacteriological loop. Slides were airdried before methanol fixation and labelling with $15 \mu \mathrm{L}$ of FITC-labelled monoclonal antibodies (Mab) against Cryptosporidium oocyst walls and Giardia cyst walls (Aqua-Glo; Waterborne Inc., NO, USA). The samples were incubated in a humid chamber for $30 \mathrm{~min}$, before removal of excess Mab and the addition of a drop of water and a cover slip. The stained smears were screened by fluorescence microscopy using the following settings: FITC: emission $-490 \mathrm{~nm}$, excitation $525 \mathrm{~nm}$, at $\times 200$ and $\times 400$ full magnification. Samples were graded after counting the number of cysts per field of view at $\times 200$ magnification; $1-9$ cysts were graded as $\mathrm{G}+, 10-50$ as $\mathrm{G}++, 51-99$ as $\mathrm{G}+++$ and counts $>100$ as $\mathrm{G}++++$

\section{Immunomagnetic separation (IMS)}

Giardia cysts were isolated from faecal samples by immunomagnetic separation (IMS) prior to DNA isolation to reduce inhibition during polymerase chain reaction (PCR) from other components in faeces. In brief, 300 $\mu \mathrm{L}$ of concentrated faeces were mixed with $10 \mu \mathrm{L}$ antiGiardia Dynabeads ${ }^{\circledR}$ (GC-combo; Life Technologies, Carlsbad, CA, USA); $80 \mu \mathrm{L}$ SurModics StabilZyme ${ }^{\circledR}, 20$ $\mu \mathrm{L}$ SL Buffer B (GC-combo; Life Technologies, USA), and $100 \mu \mathrm{L}$ phosphate-buffered saline in a $2 \mathrm{~mL}$ microfuge tube. The tubes were rotated for at least $1 \mathrm{~h}$ before separation of beads and suspension by magnetic capture, and acid dissociation. The purified sample was stored in a refrigerator at $4{ }^{\circ} \mathrm{C}$ until DNA isolation.

\section{DNA isolation}

Samples that were Eimeria-positive and/or Giardiapositive were selected for molecular characterisation by PCR. First, DNA was isolated from the cysts and oocysts using the PowerSoil ${ }^{\circledR}$ DNA isolation kit (Qiagen, USA) following the manufacturer's instructions, except that bead-beating was done twice for $60 \mathrm{~s}$ at $4 \mathrm{~m} / \mathrm{s}$ using FastPrep $24{ }^{\circledR} 5$ G (MP Biomedical, USA).

\section{PCR, electrophoresis, purification of PCR product, and sequencing}

Four genes were targeted for genotyping investigations of the isolated Giardia cysts; the $\beta$-giardin $(b g)$ gene [10], the glutamate dehydrogenase $(g d h)$ gene [11], the triosephosphate isomerase (tpi) gene [12], and the $18 \mathrm{~s}$ rRNA (18SSU) gene [13]. Three genes were targeted for genotyping investigations of the Eimeria-positive samples: the cytochrome $C$ oxidase I (coi) gene [14], the $18 \mathrm{~s}$ rRNA (18SSU) gene [15], and the internal transcribed spacer (its) gene [16] (Table 1)

\section{PCR and sequencing}

In all cases, the primary PCR consisted of $8.3 \mu \mathrm{L}$ PCR water, $1 \mu \mathrm{L}$ forward and $1 \mu \mathrm{L}$ reverse primers (at a final concentration of $0.1 \mathrm{mM}), 0.2 \mu \mathrm{L}$ BSA $(20 \mathrm{mg} / \mathrm{L}), 12.5 \mu \mathrm{L}$ of $2 \times$ DreamTaq Green PCR Master Mix (Thermo Scientific) and $2 \mu \mathrm{L}$ of template DNA. For each PCR, positive control (P101, G. duodenalis cysts, human isolate $\mathrm{H}-3$, Assemblage B, Waterborne Inc, LA, USA) and negative control (lab-grade purified water) were included. PCR products were visualized by electrophoresis on $2 \%$ agarose gel with $\mathrm{SYBR}^{\mathrm{TM}}$ Safe DNA Gel Stain (Life Technologies, CA, USA). When positive results were obtained, the DNA amplicons were purified using ExoSAP-IT ${ }^{\mathrm{TM}}$ PCR Product Cleanup Reagent (Affymetrix USB, OH, USA) and sent to Macrogen, Netherlands for sequencing in both directions. Sequences from both directions were examined, then assembled and manually corrected by analysis of the chromatograms using the program Geneious $^{\mathrm{TM}}$ 10.1.2 software (New Zealand). Sequence comparisons conducted using the National Center for Biotechnology Information Basic Local Alignment Tool (NCBI BLAST, MD, USA). Sequences were submitted to GenBank and have been assigned Accession Numbers (see "Results" section).

\section{Data description}

Microsoft Excel was used to calculate the mean and median of egg/oocyst excretion per g (EPG/OPG) faeces, as well as percentages of positive samples between age groups and areas. Confidence intervals were calculated using the online statistical tool VassarStats [17]. 
Table 1 Giardia duodenalis and Eimeria spp. primers used in this study

\begin{tabular}{|c|c|c|c|c|}
\hline Primer name & Primer sequence & Target & Prod. Size & Reference \\
\hline \multicolumn{5}{|l|}{ Giardia primers } \\
\hline GDHeF & TCAACGTYAAYCGYGGYTTCCGT & bg & 432 & [10] \\
\hline GDHiR & GTTRTCCTTGCACATCTCC & & & \\
\hline GDHiF & CAGTACAACTCYGCTCTCGG & & & \\
\hline G7 & AAGCCCGACGACCTCACCCGCAGTGC & gdh & 515 & [11] \\
\hline G759 & GAGGCCGCCCTGGATCTTCGAGACGAC & & & \\
\hline$\beta G i a r F$ & GAACGAGATCGAGGTCCG & & & \\
\hline$\beta$ GiarR & CTCGACGAGCTTCGTTGTT & & & \\
\hline AL4303 & ATCCGGTCGATCCTGCCG & tpi & 255 & [12] \\
\hline AL4305 & AGGATCAGGGTTCGACT & & & \\
\hline AL4304 & CGGTCGATCCTGCCGGA & & & \\
\hline AL4306 & GGCGGAGGATCAGGGT & & & \\
\hline $\mathrm{RH} 11$ & CATCCGGTCGATCCTGCC & $18 S S U$ & 292 & [13] \\
\hline $\mathrm{RH} 4$ & AGTCGAACCCTGATTCTCCGCCAGG & & & \\
\hline \multicolumn{5}{|l|}{ Eimeria primers } \\
\hline Cocci_COI_For & GGTTCAGGTGTTGGTTGGAC & coi & $\sim 800$ & [14] \\
\hline Cocci_COI_Rev & AATCCAATAACCGCACCAAG & & & \\
\hline TK2 & GGTTGATCCTGCCAGTAGTC & $18 S S U$ & $\sim 1.800$ & [15] \\
\hline ets2 & AATCCCAATGAACGCGACTCA & & & \\
\hline TK1 & AGTAGTCATATGCTTGTCTC & & & \\
\hline ITS-For & GCAAAAGTCGTAACACGGTTTCCG & its & $200-440$ & [16] \\
\hline ITS-Rev & CTGCAATTCACAATGCGTATCGC & & & \\
\hline
\end{tabular}

\section{Results}

\section{Overview}

At least 8 parasite genera were detected in the samples. Endoparasites were found in 108 of the 114 samples $(94.7 \%, 95 \%$ CI $89-97.6)$ and 87 of the 114 samples (76.3\%, 95\% CI 67.7-83.2) contained parasites belonging to more than one genus. Strongylid and Capillaria eggs were the most common findings, followed by protostrongylid larvae and Eimeria oocysts.

\section{Occurrence of different parasites}

Low levels and high occurrence of parasite eggs were found in the samples from both regions, although the occurrence in animals from Spierttagáisá seemed higher than in than from Neiden for Dictyocaulus larvae, G. duodenalis cysts, strongylid eggs, and Nematodirinae eggs.

In contrast, the occurrence of Capillaria eggs and protostrongylid larvae seemed higher in animals from Neiden. Results are summarised in Tables 2 and 3.

\section{Speciation of Eimeria oocysts Morphology}

Eimeria oocysts were not found in samples from adult reindeer. In Neiden and Spierttagáisá, 43\% (19/44) and
$21 \%(7 / 34)$ of the calves, respectively, were excreting Eimeria oocysts.

Eimeria oocysts of comparatively large and small sizes were successfully isolated from 5 samples. The average size of the larger oocysts (length $\mathrm{x}$ width) $(\mathrm{n}=26)$ was $35.2 \times 26.6 \mu \mathrm{m}$ (range: $31-40 \times 25-30 \mu \mathrm{m}$ ), [Standard Deviation; SD: $33.5-37.0-\times 24.8-28.4]$. Average size (length $\mathrm{x}$ width) of sporocysts $(\mathrm{n}=20)$ was $19.9 \times 9.9 \mu \mathrm{m}$ (range: $15-22 \times 8.4-10 \mu \mathrm{m}$ ), [SD: $18.8-22.6 \times 9.7-$ $10.1 \mu \mathrm{m}]$. These measurements are compatible with the species E. rangiferis [9].

In one sample from Spierttagáisá, only the smaller Eimeria oocysts were detected. The average size (length $\mathrm{x}$ width) of these oocysts $(\mathrm{n}=6)$ was $16 \times 14.5 \mu \mathrm{m}$ (range: $15-17 \mu \mathrm{m} \times 14-15 \mu \mathrm{m}$ ), [SD: 15.4-16.6] $\mathrm{x}$ [SD: $14.0 \times 15.0]$. These measurements are compatible with the species E. mayeri [9]. Screening of several subsamples suggested that this species of Eimeria occurred as a monoinfection.

\section{Molecular analyses}

We did not obtain amplification of Eimeria DNA using the its gene primer set. However, several sequences obtained using the coi gene and 18SSU gene primers were of good quality and showed close genetic relationships with other Eimeria species when aligned with sequences 
Table 2 Occurrence of parasites in faecal samples from semi-domesticated reindeer in Spierttagáisá, Finnmark

\begin{tabular}{|c|c|c|c|c|c|c|}
\hline Grazing area & n positive & $\%$ positive & $95 \% \mathrm{Cl}$ & Median & Mean & Range \\
\hline Spierttagáisá & $\begin{array}{l}N \text { total }=46 \\
N \text { calves }=34 \\
N \text { adults }=12\end{array}$ & & & epg/opg & epg/opg & epg/opg \\
\hline Strongylid & 39 & 84.8 & $71.8-92.43$ & 30 & 46 & $10-250$ \\
\hline Strongylid (calves) & 30 & 88.2 & 73.4-95.3 & 35 & 45 & $10-140$ \\
\hline Strongylid (adults) & 9 & 75.0 & $46.8-91.1$ & 30 & 52 & $10-250$ \\
\hline Nematodirinae sp. & 21 & 45.7 & $32.2-59.8$ & 40 & 63 & $10-280$ \\
\hline Nematodirinae sp. (calves) & 16 & 47.1 & $31.5-63.3$ & 45 & 73 & $10-280$ \\
\hline Nematodirinae sp. (adults) & 5 & 41.7 & $19.3-68.1$ & 10 & 32 & $10-110$ \\
\hline Capillaria sp. & 1 & 2.2 & $0.4-11.3$ & 20 & - & - \\
\hline Capillaria sp. (calves) & 0 & 0 & $0-10.2$ & - & - & - \\
\hline Capillaria sp. (adults) & 1 & 1 & $1.5-35.4$ & 20 & - & - \\
\hline Moniezia sp. & 10 & 21.7 & $12.3-35.6$ & - & - & - \\
\hline Moniezia sp. (calves) & 9 & 26.5 & $14.6-43.1$ & - & - & - \\
\hline Moniezia sp. (adults) & 1 & 8.3 & $1.5-35.4$ & - & - & - \\
\hline Dictyocaulus sp. & 15 & 32.6 & $20.1-47.0$ & - & - & - \\
\hline Dictyocaulus sp. (calves) & 14 & 41.2 & $26.4-57.8$ & - & - & - \\
\hline Dictyocaulus sp. (adults) & 1 & 8.3 & $1.5-35.4$ & - & - & - \\
\hline Protostrongylid L1 & 1 & 2.2 & $0.4-11.3$ & - & - & - \\
\hline Protostrongylid L1 (calves) & 0 & 0 & $0-10.2$ & - & - & - \\
\hline Protostrongylid L1 (adults) & 1 & 8.3 & $1.5-35.4$ & - & - & - \\
\hline Eimeria sp. & 7 & 15.2 & $7.6-28.2$ & 600 & 6886 & $200-45,200$ \\
\hline Eimeria sp. (calves) & 7 & 20.6 & $10.4-36.8$ & 500 & 6886 & $200-45,200$ \\
\hline Eimeria sp. (adults) & 0 & 0 & $0-30.1$ & - & - & - \\
\hline Giardia duodenalis & 5 & 10.9 & $4.7-23.0$ & - & - & - \\
\hline G. duodenalis (calves) & 5 & 14.7 & $6.5-30.1$ & - & - & - \\
\hline G. duodenalis (adults) & 0 & 0 & $0-30.1$ & - & - & - \\
\hline Cryptosporidium sp. & 0 & 0 & $0-7.7$ & - & - & - \\
\hline Cryptosporidium sp. (calves) & 0 & 0 & $0-10.2$ & - & - & - \\
\hline Cryptosporidium sp. (adults) & 0 & 0 & $0-30.1$ & - & - & - \\
\hline
\end{tabular}

in the NCBI GenBank database. Five sequences have been submitted to GenBank.

From the sample containing only oocysts identified as $E$. mayeri by microscopy, the sequence results produced sequences of good quality from both the coi gene and $18 S S U$ gene primers (GenBank Accession Numbers: MK170375.1 (18SSU) and MT987642 (coi). As several subsample screenings confirmed this was the only Eimera species present, the sequence aligning to MT987642, though from another sample, were thus confirmed to belong to this species as well (MT987644). The closest match in GenBank for the coi sequences was Eimeria mephtidis (91.81\% identity) and for 18SSU it was Eimeria subspherica (97.96\% identity).

From two samples containing larger oocysts confirmed to belong to E. rangiferis the sequence results produced sequences of good quality from the coi gene primer (GenBank Accession numbers: MT987643 and MT987645). These sequences were identical to each other, but not to the sequences obtained from the sample containing only E. mayeri oocysts. Among published sequences in GenBank Eimeria melogale was the closest match (92.02\% similarity).

\section{Giardia cysts}

Overall, Giardia cysts were found in 5\% (6/114) of the samples collected. One sample was from Neiden, and five were from Spierttagáisá. Of these six positive samples, four had a low number of cysts $(+)$, one had a moderate number of cysts $(++)$, and one had a high number of cysts $(+++)$.

PCR was attempted for all six positive samples, and positive results were obtained from three of them. Different genetic loci gave the following positive results: 
Table 3 Occurrence of parasites in faecal samples from semi-domesticated reindeer in Neiden, Finnmark

\begin{tabular}{|c|c|c|c|c|c|c|}
\hline Grazing area & n positive & $\%$ positive & $95 \% \mathrm{Cl}$ & Median & Mean & Range \\
\hline Neiden & $\begin{array}{l}N \text { total }=68 \\
N \text { calves }=44 \\
N \text { adults }=24\end{array}$ & & & epg/opg & epg/opg & epg/opg \\
\hline Strongylid & 32 & 47.1 & $35.7-58.8$ & 10 & 16 & $10-40$ \\
\hline Strongylid (calves) & 22 & 50.0 & $35.8-64.2$ & 10 & 16 & $10-40$ \\
\hline Strongylid (adults) & 10 & 41.7 & $24.5-61.2$ & 10 & 15 & $10-40$ \\
\hline Nematodirinae sp. & 6 & 8.8 & $4.1-17.9$ & 20 & 18 & $10-30$ \\
\hline Nematodirinae sp. (calves) & 6 & 13.6 & $6.4-26.7$ & 15 & 18 & $10-30$ \\
\hline Nematodirinae sp. (adults) & 0 & 0 & $0-13.8$ & - & - & - \\
\hline Capillaria sp. & 47 & 69.10 & $57.4-78.8$ & 30 & 37 & $10-120$ \\
\hline Capillaria sp. (calves) & 34 & 77.3 & $63.0-87.2$ & 35 & 37 & $10-120$ \\
\hline Capillaria sp. (adults) & 13 & 54.2 & $35.1-72.1$ & 30 & 37 & $10-90$ \\
\hline Moniezia sp. & 9 & 13.2 & $7.1-23.3$ & - & - & - \\
\hline Moniezia sp. (calves) & 9 & 20.5 & $11.2-34.5$ & - & - & - \\
\hline Moniezia sp. (adults) & 0 & 0 & $0-13.8$ & - & - & - \\
\hline Dictyocaulus sp. & 1 & 1.5 & $0.3-7.9$ & - & - & - \\
\hline Dictyocaulus sp. (calves) & 1 & 2.3 & $0.4-11.8$ & - & - & - \\
\hline Dictyocaulus sp. (adults) & 0 & 0 & $0-13.8$ & - & - & - \\
\hline Protostrongylid L1 & 45 & 66.2 & $54.4-76.3$ & - & - & - \\
\hline Protostrongylid L1 (calves) & 26 & 59.1 & $44.4-72.3$ & - & - & - \\
\hline Protostrongylid L1 (adults) & 19 & 79.2 & $59.5-90.1$ & - & - & - \\
\hline Eimeria spp. & 19 & 27.9 & 18.7-39.6 & 600 & 1663 & $200-13,000$ \\
\hline Eimeria sp. (calves) & 19 & 43.2 & $29.7-57.8$ & 600 & 1663 & $200-13,000$ \\
\hline Eimeria sp. (adults) & 0 & 0 & $0-13.8$ & - & - & - \\
\hline Giardia duodenalis & 1 & 1.5 & $3.5-7.9$ & - & - & - \\
\hline G, duodenalis (calves) & 1 & 2.3 & $0.4-11.8$ & - & - & - \\
\hline G. duodenalis (adults) & 0 & 0 & $0-13.8$ & - & - & - \\
\hline Cryptosporidium sp. & 0 & 0 & $0-4.7$ & - & - & - \\
\hline Cryptosporidium sp. (calves) & 0 & 0 & $0-8.0$ & - & - & - \\
\hline Cryptosporidium sp. (adults) & 0 & 0 & $0-13.8$ & - & - & - \\
\hline
\end{tabular}

Eggs, (oo)cysts and larvae found in faecal samples from 114 reindeer from two grazing districts in Finnmark. Positive samples, occurrence, 95\% confidence intervals, eggs per gram (epg), oocysts per gram (opg), their mean and median and range of counts

bg gene 33\% (2/6), gdh gene $17 \%$ (1/6), $18 S S U$ gene $33 \%$ $(2 / 6)$ and tpi gene $33 \%(2 / 6)$.

Of the sequences obtained, all belonged to Assemblage A, sub-assemblage AI. The sequences have been deposited in GenBank under the Accession Numbers: MH155687, MH155689 for the $b g$ sequences, MH051905 for the $g d h$ sequence, MH04726-MH047247 for the $18 S S U$-sequences and MH155689-MH155690 for the tpi sequences.

\section{Cryptosporidium sp.}

Cryptosporidium sp. oocysts were not detected in the samples.

\section{Discussion}

The main finding in this study was that a low number and a high prevalence of different endoparasites seem to be common in apparently healthy reindeer from the two areas. The majority of samples were positive for one or more parasite species. Although the sample size and area were limited, the results are consistent with those from earlier and larger studies reporting that semi-domesticated reindeer harbour a high prevalence of subclinical, low-intensity, mixed infections of gastrointestinal parasites [5, 18-21].

Reindeer husbandry represents a traditional and vital production system in Troms and Finnmark county, and any factor that may impose a constraint on their productivity may impact the local economy. Information on 
endoparasites in semi-domesticated reindeer in Norway is limited, and the results of this study only provide a snapshot overview among a low number of animals from two regions. All animals were slaughter animals that underwent ante- and post-mortem inspections; no manifestations of clinical disease were observed.

From the parasites detected in this study, of particular note is the presence of a zoonotic assemblage of $G$. duodenalis. Such infections have not previously been recorded from semi-domesticated reindeer in Norway.

A range of trichostrongylid nematodes have previously been reported from reindeer [e.g., 22-26, and reindeer are susceptible to infection with strongylids typically found in domestic animals [27]. Nevertheless, the dominant gastrointestinal strongylid species in reindeer has been reported to be the abomasal trichostrongylid Ostertagia gruehneri [28], and we assume that this is the species that was found in our study, given that the natural pastures in this study were predominantly grazed by reindeer.

Ostertagia gruehneri egg output generally peaks midsummer or in late summer-autumn [29], and the burden of adult $O$. gruehneri has been found to increase from autumn to spring in Svalbard reindeer [30]. O. gruehneri infections have been associated with decreased food intake, loss in body condition and reduced fecundity in reindeer [31]. Egg counts of O. gruehneri have been shown to decrease during the winter months, although this decrease followed the reduction in adult nematode burdens in the abomasum and an increase in larval stages in the abomasal mucosa [19]. In this study, the strongylid egg counts were low, which may not reflect the actual abomasal nematode burden, due to the time and logistics of sampling.

Nematodirines are found in the small intestine of mainly young ruminants, and the two species considered specific to reindeer are Nematodirus tarandi and Nematodirella longissemispiculata. Nematodirus skrjabini has also been reported, but this may be a synonym for $N$. tarandi [30]. A recent epidemiological study from Fennoscandia reported a $22.1 \%$ prevalence of Nematodirinae eggs in reindeer calves [5], which seems lower than our findings. A survey from four areas in northern Finland [33] only found Nematodirinae spp. in reindeer calves and concluded that reindeer Nematodirinae infection appears similar to that of Nematodirus spp. in domestic ruminants, where infected young animals rapidly develop a strong immune response to re-infection.

Capillaria sp. is a nematode commonly found in reindeer of all ages. Eggs are shed intermittently, which may underestimate the true prevalence when single samples are examined, and in contrast to O. gruehneri, eggs are shed even in mid-winter [20]. A study using consecutive sampling [19] found that $60 \%$ of calves in northern Finland shed eggs during the winter, with an age-related difference in egg output. A recent survey [5] found a 9.4\% prevalence in calves from both Finland and Norway. The seemingly geographical differences in this study may reflect local establishment of parasite life cycles.

Moniezia spp. tapeworms are probably a common parasite of reindeer in Fennoscandia, although reports are scant. Studies from the late 1970s on semi-domesticated reindeer in Reinøya, Troms found an 18\% prevalence during late summer [34], an $18 \%$ prevalence in calves from Northern Finland was reported in 2008 [35], and a prevalence of $28 \%$ was found in Finnish and Norwegian reindeer calves in 2019 [5]. Moniezia infections in reindeer are reported to be most common in young animals [36]. The overall impact of Moniezia spp. on reindeer in Fennoscandia is yet unknown, though low intensity infections are, as with Moniezia infections in domestic ruminants, assumed to be of little clinical importance.

Different species of Dictyocaulus have been reported from both wild and domestic ruminants in the Holarctic, with $D$. eckerti considered as the most common lungworm of reindeer [37]. Prevalence data on lungworm infection in semi-domesticated reindeer in Norway are scarce, although a longitudinal study from 1978 to 1979 found a prevalence ranging from 0 to $42 \%$ [34], with the highest proportion of positive samples collected in May and June. Pathological changes from lungworm infection inspected at a slaughterhouse during 1978-1980 amounted to less than $1 \%$, but it was noted that this may be a misrepresentation of the prevalence, as animals usually develop immunity with age [22]. In our survey, the occurrence was considerably lower than recent findings from wild reindeer populations in Norway, where prevalences from 28 to $80 \%$ were found [38]. Although presumed to have an overall low prevalence in semidomesticated reindeer, outbreaks of disease due to Dictyocaulus spp. have been reported in reindeer calves, sometimes with the contribution of opportunistic bacteria, and have caused severe mortality in calves during spring [39].

Elaphostrongylus rangiferi, or the meningeal worm of reindeer, is widespread among semi-domesticated reindeer in Norway [40]. Prevalences up to $68 \%$ have previously been found in calves [41], and up to $100 \%$ in adult reindeer. A recent study on wild reindeer found prevalences up to $89 \%$ in some herds [38]. In contrast to the direct life cycle of Dictyocaulus spp., E. rangiferi requires a gastropod intermediate host to complete its life cycle, and further development inside this intermediate host is temperature dependent. Warm summers have been followed by mass outbreaks of neurological brainworm infection. One study [42] concluded that above-mean 
summer temperatures facilitate mass development of infective $E$. rangiferi larvae in the gastropod intermediate hosts and thus can cause epidemics of cerebrospinal elaphostrongylosis with high mortalities, especially among calves. In the unusually warm summer of 2018, reindeer herders in Norway reported an outbreak of elaphostrongylosis; one herder apparently lost 70 animals of different ages [43]. Under conditions of predicted climate change, such outbreaks of elaphostrongylosis may increase.

We believe the protostrongylid larvae found in this study belong to the species $E$. rangiferi, as they did not have the shorter length and granulated appearance of Muellerius capillaris lungworms. Furthermore, they are unlikely to be Neostrongylus spp., Protostrongylus spp. and Cystocaulus spp., as the larvae found in our samples had the characteristic kinked tail and dorsal spine of Elaphostrongylus spp. However, we cannot exclude that at least some of the larvae in our samples could be Elaphostrongylus alces or Vareostrongylus eleguneniensis, resulting from spillover from the locally increasing moose population, although, based on previous reports, E. rangiferi may be the most plausible species in this case.

Eight species of Eimeria and one Isospora species have been described from reindeer. Five of these are based on oocysts recovered from faeces from reindeer in Russia: E. arctica, E. mayeri, E. mühlensi, E. tarandina and I. rangiferis [44-46], two are based on oocysts recovered from faeces from reindeer in Iceland; E. rangiferis and $E$. hreindyria [9], and a new species, E. tuttui, was described from reindeer in Greenland in 2016 [47]. To our knowledge, this study provides the first identified species of Eimeria found in semi-domesticated reindeer in Norway. As reindeer from Iceland are descendants of Norwegian reindeer, it is not surprising that they share the same species of this host-specific parasite.

Clinical disease associated with Eimeria spp. is not considered common in free-ranging wild reindeer. A study from Finland found the prevalence in semi-domesticated reindeer calves to be $35 \%$ [48], whereas a survey of wild reindeer calves from Iceland found a 3.6\% prevalence of Eimeria oocysts in faeces [25]. Little is known regarding the pathogenicity caused by Eimeria infections in reindeer, and, under natural grazing conditions, clinical infections are probably not common [21]. As infection with direct life cycle parasites is favoured by crowding in enclosures, Eimeria spp. could be among the parasites that will increase in burden and prevalence in semi-domesticated reindeer if duration and/or frequency of gathering in enclosures (e.g. calving and feeding) increase, and pasture area continue to fragment and decrease.
G. duodenalis is a common intestinal parasite found in mammals, which, depending on assemblage, has both anthropozoonotic and zoonotic potential. Assemblages $A$ and $B$ have a wide host spectrum and are further divided into different sub-assemblages based on genetic diversity. Some sub-assemblages are found in both humans and other mammals, giving a strong indication that the genotype is zoonotic. Sub-assemblage AI is preferentially found in animals, AII is more often found in humans, while AIII is exclusively found in animals, particularly wildlife [49]. The detection of assemblage AI in reindeer calf faeces from Neiden and Spierttagáisá indicates a zoonotic potential. Although G. duodenalis of sub-assemblages AI and AII have previously been found in wild reindeer and moose in Norway [50], this has not been previously described in semi-domesticated reindeer in Norway.

Cryptosporidium spp. have been sporadically detected in reindeer faeces. An epidemiological study from northern Finland and Norway did not detect Cryptosporidium spp. in semi-domesticated reindeer [51], but infections have been observed in reindeer calves and were associated with diarrhoea [21]. In wild reindeer, Cryptosporidium spp. infections are considered uncommon and have not been associated with clinical disease [52]. A cumulative prevalence of $100 \%$ G. duodenalis cysts and $23 \%$ Cryptosporidium oocysts found in faeces from semidomesticated reindeer calves from age 0 to 33 days in a study from Northern Finland [53] demonstrates that these parasites are present and have possibly established in some semi-domesticated reindeer herds.

Pasture parasite development is dependent on environmental factors like temperature and humidity, thus their prevalence is likely to vary throughout the year, being higher during summer and lower during winter [19].

In this study, samples were collected and stored inconsistently. Samples from one area were stored at varying air temperatures (ranging between approximately $-15^{\circ}$ and $-30{ }^{\circ} \mathrm{C}$ ) and this may have affected the results. In addition, samples were collected during late autumn and winter, and previous studies have found that egg output decreases in this period due to changes in the gastrointestinal parasite population structure with fewer adult, egglaying worms, or a natural regulation of egg production during a season where conditions for free-living stages on pasture are suboptimal [19]. Our results should thus be interpreted with caution and cannot be representative as a true prevalence or burden. The small sample size is also a limitation of the study, although indicating the need for further investigations with more targeted and larger sample sizes.

In this study we found parasites in a high number of samples, but none of the sampled animals shed quantities 
that are considered to reflect clinical relevance when compared to infections acquired by domestic ruminants kept under more intensive husbandry. Contributing factors to the low intensity of infection can be the time of sampling and low animal or parasite density on feeding grounds and pasture.

During the last decades, the northernmost counties of Norway have experienced an increase in tourism. This has, in turn, increased the local globalisation in this area.

The need for and use of supplementary feeding has increased as countermeasures for difficult winter seasons when food availability is restricted, pasture areas are decreased, and climate changes, as well as abnormal seasonal weather resulting in higher temperatures and increased precipitation making food less accessible when snow turns to rain and then ice [54]. Unstable winters, with mild weather and coastal climates moving further inland, have resulted in unpredictable access to pasture resources for reindeer in winter. We speculate that these changes may increase the need for calving inside protective fences and thus feeding inside these fences.

Supplementary feeding and keeping reindeer in protective fences are also a move away from traditional reindeer herding. Although this may increase tameness and facilitate monitoring of the herd [55], it can also result in higher animal densities and thus greater infection pressure.

As parasitic infections in reindeer and their clinical significance are still largely unknown and reindeer husbandry faces an uncertain future, we hope that the results we obtained from this study may be part of a future reference for further studies of these relatively unexplored areas of parasitology and epidemiology. We also hope it may contribute to a better understanding of the potential hazards these infections may represent for a traditional industry that is vulnerable to seemingly unavoidable future changes.

\section{Conclusions}

We detected a high prevalence, although low burdens, of faecal endoparasites (perhaps reflecting time of sampling) in a limited number of samples from semi-domesticated reindeer in Finnmark, Norway.

With many reindeer harbouring parasites, as shown in this and other studies, changes in weather, climate, and husbandry favourable for parasite accumulation and development could result in exacerbated infection pressure and development of parasitic diseases in semidomesticated reindeer. Considering the ongoing climate change, there is a clear need to broaden our knowledge regarding the various challenges that reindeer husbandry might face.

\section{Acknowledgements}

The authors are grateful to the ParaWild Project, supported by the Olav Thon Foundation, for financing the publication of this article. Helene Weydahl Guttorm for the samples and valuable input to the manuscript, Stine Bull Aurbakken, Mattilsynet, and Arnt Inge Guttorm at MT-Slakt, Kautokeino, for their hospitality, support and help in facilitating the collection of samples. Bror Jonathan Myhren and Tamirat Tefera Temesgen, NMBU, for help with the laboratory analysis and Lisbeth Hektoen, NMBU, for proof-reading the indepth study on which this article is based.

\section{Prior publication}

Preliminary data were presented in a poster at the 8th Conference of the Scandinavian-Baltic Society for Parasitology (SBSP) and the Annual Meeting of the European Veterinary Parasitology College (EVPC) October 10-11, 2019 in Copenhagen, Denmark.

\section{Authors' contributions}

$\mathrm{LI}, \mathrm{AML}$ and EKS carried out the main bulk of the sampling and analysis and are all considered first authors on this manuscript. KRT carried out molecular analysis. LJR contributed to the analysis of the results and the writing process. KSU conceived the study and contributed to both faecal and molecular analysis. All authors contributed to drafting the manuscript. All authors read and approved the final manuscript.

\section{Funding}

This study was a student project at Norwegian University of Life Science, Faculty of Veterinary Medicine and received internal funding for sample collection and analysis. Publication of this article is financed by the ParaWild Project, which is supported by the Olav Thon Foundation.

\section{Availability of data and materials}

The datasets used and/or analysed during the current study are available from the corresponding author on reasonable request. The sequences obtained have been assigned the following accession numbers: Giardia duodenalis: MH155687, MH155689, MH051905, MH04726-MH047247 and MH155689MH155690. Eimeria spp: MK170375.1, MT 987,642, MT987643, MT987644 and MT987645.

\section{Declarations}

\section{Ethics approval and consent to participate}

This study did not require official or institutional ethical approval.

\section{Competing interests}

The authors declare that they have no competing interests.

\section{Author details}

${ }^{1}$ Parasitology Laboratory, Department of Paraclinical Sciences, Faculty of Veterinary Medicine, Norwegian University of Life Sciences, Adamstuen Campus, Sentrum, PO Box 369, Oslo 0102, Norway. ${ }^{2}$ Faculty of Bioscience and Aquaculture, Nord University, Bodø, Norway.

Received: 4 October 2020 Accepted: 9 March 2021

Published online: 23 March 2021

References

1. Hansen H, Kapperud G, Mysterud A, Solberg EJ, Strand O, Tranulis M, et al. CWD in Norway -a state of emergency for the future of cervids (Phase II). European J Nutr Food Saf. 2019;12:297-300.

2. Ravna $\varnothing$. Norwegian online encyclopedia. Reindeer grazing area. https:// snl.no/reinbeiteområde. (2017) Accessed 25 Feb 2021 [in Norwegian].

3. Ministry of Agriculture and Food website. Reindeer husbandry. https:// www.regjeringen.no/en/topics/food-fisheries-and-agriculture/reindeerhusbandry/reindeer-husbandry/id2339774/ https://www.regjeringen. no/en/topics/food-fisheries-and-agriculture/reindeer-husbandry/reind eer-husbandry/id2339774/ (2017) Accessed 25 Feb 2021.

4. Directorate of Agriculture. Total accounts for the Reindeer Husbandry industry. Accounts 2018 and budget 2019. Report Nr 31;2019 https:// 
docplayer.me/188254555-Totalregnskap-for-reindriftsnaeringen.html (2019) Accessed 25 Feb 2021 [in Norwegian].

5. Jokelainen P, Moroni B, Hoberg E, Oksanen A, Laaksonen S. Gastrointestinal parasites in reindeer (Rangifer tarandus tarandus) calves from Fennoscandia: An epidemiological study. Vet Parasitol Reg Stud Rep. 2019;16:100277.

6. Bjørklund PK. Rekdal Y. Strand GH. Area accounts for outfields. Area statistics for Finnmark. Resource overview from Forests and landscapes 2015;27:33 [in Norwegian].

7. Lavsund S, Nygrén T, Solberg EJ. Status of moose populations and challenges to moose management in Fennoscandia. Alces. 2003;39:109-30.

8. Gibbons LM, Jacobs DE, Fox MT. Hansen J. The RVC/FAO guide to veterinary diagnostic parasitology. Faecal examination of farm animals for helminth parasites. https://www.rvc.ac.uk/review/Parasitology/Index/ Index.htm Accessed on 25 Feb 2021

9. Gunðmundsdóttir B, Skirnisson K. Description of a new Eimeria species and redescription of Eimeria mayeri (Protozoa: Eimeriidae) from wild reindeer Rangifer tarandus in Iceland. J Parasitol. 2005;91:353-7.

10. Lalle M, Pozio E, Capelli G, Bruschi F, Crotti D, Cacciò SM. Genetic heterogeneity at the $\beta$-giardin locus among human and animal isolates of Giardia duodenalis and identification of potentially zoonotic subgenotypes. Int J Parasitol. 2005;35:207-13.

11. Read CM, Monis PT, Thompson RCA. Discrimination of all genotypes of Giardia duodenalis at the glutamate dehydrogenase locus using PCR-RFLP. Infect Genet Evol. 2004;4:125-30.

12. Sulaiman IM, Fayer R, Bern C, Gilman RH, Trout JM, Schantz PM, et al. Triosephosphate isomerase gene characterization and potential zoonotic transmission of Giardia duodenalis. Emerg Infect Dis. 2003;9:1444-52.

13. Hopkins RM, Meloni BP, Groth DM, Wetherall JD, Reynoldson JA, Thompson RA. Ribosomal RNA sequencing reveals differences between the genotypes of Giardia isolates recovered from humans and dogs living in the same locality. J Parasitol. 1997;83:44-51.

14. Ogedengbe JD, Hanner RH, Barta JR. DNA barcoding identifies Eimeria species and contributes to the phylogenetics of coccidian parasites (Eimeriorina, Apicomplexa, Alveolata). Int J Parasitol. 2011;41:843-50.

15. Kokuzawa T, Ichikawa-Seki M, Itagaki T. Determination of phylogenetic relationships among Eimeria species, which parasitize cattle, on the basis of nuclear 18S rDNA sequence. J Vet Med Sci. 2013;75:1427-31.

16. Kawahara F, Zhang G, Mingala CN, Tamura Y, Koiwa M, Onuma M, et al. Genetic analysis and development of species-specific PCR assays based on ITS-1 region of rRNA in bovine Eimeria parasites. Vet Parasitol. 2010:174:49-57.

17. Lowry R. The confidence interval of a proportion, no continuity correction. Confidence Interval of a Proportion (vassarstats.net) Accessed on 25 Feb 2021

18. Halvorsen O. Epidemiology of reindeer parasites. Parasitol Today. 1986;2:334-9.

19. Hrabok JT, Oksanen A, Nieminen M, Waller PJ. Population dynamics of nematode parasites of reindeer in the sub-arctic. Vet Parasitol. 2006;142:301-11.

20. Oksanen A. Endectocide treatment of the reindeer. Rangifer. 1999:1-118.

21. Josefsen TD, Oksanen A, Gjerde B. Parasites in reindeer in Fennoscandia, an overview [in Norwegian]. Norsk Veterinærtidskrift. 2014;126:185-201.

22. Haugerud RE, Hemmingsen W. Lungworms. Parasites in reindeer [in Norwegian]. Ottar. 1986;161:16-7.

23. Bye K. Abomasal nematodes from three Norwegian wild reindeer populations. Can J Zool. 1987;65:677-80

24. Fruetel M, Lankester MW. Gastrointestinal helminths of woodland and barren ground caribou (Rangifer tarandus) in Canada, with keys to species. Can J Zool. 1989;67:2253-69.

25. Gunðmundsdóttir B. Parasites on reindeer in Iceland [in Icelandic].MsC Thesis University of Iceland, Reykjavík, 2006;100.

26. Steele J, Orsel K, Cuyler C, Hoberg EP, Schmidt NM, Kutz SJ. Divergent parasite faunas in adjacent populations of West Greenland caribou: natural and anthropogenic influences on diversity. Int J Parasitol Parasites Wildl. 2013;2:197-202.

27. Hrabok JT, Oksanen A, Nieminen M, Rydzik A, Uggla A, Waller PJ. Reindeer as hosts for nematode parasites of sheep and cattle. Vet Parasitol. 2006;136:297-306

28. Kutz SJ, Laaksonen S, Åsbakk K, Nilssen AC. Parasitic I. Infections and Diseases. In: Tryland M, Kutz SJ, editors. Reindeer and Caribou - health and Disease. Boca Raton. CRC Press, 2018.p.177-237.
29. Jokelainen P, Moroni B, Hoberg E, Oksanen A, Laaksonen S. Gastrointestinal parasites in reindeer (Rangifer tarandus tarandus): A review focusing on Fennoscandia. Vet Parasitol Reg Stud Reports. 2019;17:100317.

30. Halvorsen $\mathrm{O}$, Bye K. Parasites, biodiversity, and population dynamics in an ecosystem in the high arctic. Vet Parasitol. 1999;84:205-27.

31. Albon SD, Stien A, Irvine RJ, Langvatn R, Ropstad E, Halvorsen O. The role of parasites in the dynamics of a reindeer population. Proc Royal Soc Lond B Biol Sci. 2002;269:1625-32.

32. Hoberg EP, Kocan AA, Rickard LG. Gastrointestinal strongyles in wild ruminants. In Samuel W, Pybus MJ, Kocan AA, editors. Parasitic diseases of wild mammals. lowa state University Press. 2001:193-227.

33. Hrabok JT, Oksanen A, Nieminen M, Waller PJ. Prevalence of gastrointestinal nematodes in winter slaughtered reindeer of northern Finland. Rangifer. 2007:27:133-9.

34. Tøllefsen L. Endoparasites in reindeer (Rangifer tarandus L.) with special emphasis on gastrointestinal Nematoda [in Norwegian]. Diss. M. Sc. Thesis. University of Troms $\varnothing$. Troms $\varnothing$, Norway, 1983

35. Laaksonen S, Oksanen A, Orro T, Norberg H, Nieminen M, Sukura A. Efficacy of different treatment regimes against setariosis (Setaria tundra, Nematoda: Filarioidea) and associated peritonitis in reindeer. Acta Vet Scand. 2008:50:49.

36. Bye K. Cestodes of reindeer (Rangifer tarandus platyrhynchus Vrolik) on the Arctic islands of Svalbard. Can J Zool. 1985;63:2885-7.

37. Höglund J, Morrison DA, Divina BP, Wilhelmsson E, Mattsson JG. Phylogeny of Dictyocaulus (lungworms) from eight species of ruminants based on analyses of ribosomal RNA data. Parasitology. 2003;127:179.

38. Handeland K, Davidson RK, Viljugrein H, Mossing A, Meisingset EL, Heum $\mathrm{M}$, et al. Elaphostrongylus and Dictyocaulus infections in Norwegian wild reindeer and red deer populations in relation to summer pasture altitude and climate. Int J Parasitol Parasites Wildl. 2019;10:188-95.

39. Kummeneje K. Dictyocaulus viviparus infestation in reindeer in northern Norway. A contribution to its epidemiology. Acta Vet Scand. 1977:18:86.

40. Davidson RK, Mørk T, Holmgren KE, Oksanen A. Infection with brainworm (Elaphostrongylus rangiferi) in reindeer (Rangifer tarandus ssp.) in Fennoscandia. Acta Vet Scand. 2020;62:1-15.

41. Halvorsen O. Andersen J. Skorping A. Lorentzen G. Infection in reindeer with the nematode Elaphostrongylus rangiferi Mitskevich in relation to climate and distribution of intermediate hosts [in Norwegian]. Proceedings of the Second International Reindeer/Caribou Symposium, 17th-21st September 1979, Røros, Norway, Part B. Direktorat for Vilt og Ferskvannsfisk. 1980:449455 [in Norwegian].

42. Halvorsen O. Reindeer parasites, weather and warming of the Arctic. Polar Biol. 2012:35:1749-52.

43. Deksne G, Davidson RK, Buchmann K, Kärssin A, Kirjušina M, Gavarāne I, et al. Parasites in the changing world-Ten timely examples from the Nordic-Baltic region. Parasite Epidemiol Control. 2020;10:e00150.

44. YakimoffWL, Matschoulsky SN, Spartansky OA. On a new coccidium from reindeer Eimeria arctica n sp. J Microsc. 1939;59:30-1.

45. Yakimoff WL, Sokoloff II, Matschoulsky SN. About the reindeer coccidia [in German]. Berl Tierarztl Wochenschr. 1936;52:535-8.

46. YakimoffWL, Matschoulsky SN, Spatansky OA. Further research on coccidiosis in reindeer [in German]. Berl Tierarztl Wochenschr. 1937;53:322.

47. Skirnisson $K$, Cuyler C. A new Eimeria species (Protozoa: Eimeriidae) from caribou in Ameralik. West Greenland Parasitol Res. 2016;115:1611-5.

48. Oksanen A, Nieminen M, Soveri T, Kumpula K, Heiskari U, Kuloharju V, et al. The establishment of parasites in reindeer calves. Rangifer Special. 1990;5:20-1.

49. Faria CP, Zanini GM, Dias GS, da Silva S, do Céu Sousa M. Molecular characterization of Giardia lamblia: first report of assemblage B in human isolates from Rio de Janeiro (Brazil). PloS ONE. 2016. Doi: https://doi.org/10.1371/ journal.pone.0160762

50. Robertson L, Forberg T, Hermansen L, Hamnes IS, Gjerde B. Giardia duodenalis cysts isolated from wild moose and reindeer in Norway: genetic characterization by PCR-RFLP and sequence analysis at two genes. J Wildl Dis. 2007:43:576-85.

51. Kemper N, Aschfalk A, Höller C. Campylobacter spp., Enterococcus spp., Escherichia coli, Salmonella spp., Yersinia spp, and Cryptosporidium oocysts in semi-domesticated reindeer (Rangifer tarandus tarandus) in Northern Finland and Norway. Act Vet Scand. 2006;48:7.

52. Kutz SJ, Ducrocq J, Verocai GG, Hoar BM, Colwell DD, Beckmen KB, et al. Parasites in ungulates of Arctic North America and Greenland: a view of 
contemporary diversity, ecology, and impact in a world under change. Academic Press Adv Parasitol. 2012;79:99-252.

53. Niine T, Peetsalu K, Nieminen M, Oksanen A, Soveri T, Orro T. Giardia and Cryptosporidium infections in neonatal reindeer calves: Relation to the acute phase response. Comp Immunol Microb. 2017:54:45-50.

54. Tryland M. Are we facing new health challenges and diseases in reindeer in Fennoscandia? Rangifer. 2012:32:35-47.

55. Eilertsen SM, Winje E. Supplementary feeding of reindeer - Supplementary feeding of reindeer during difficult operational situations, or as part of the operational arrangement during collection and movement of the reindeer herd [In Norwegian]. NIBIO POP.2017;3:1-8. https://nibio.brage.unit.no/ nibio-xmlui/handle/11250/2484415 Accessed on 25 Feb 2021.

\section{Publisher's Note}

Springer Nature remains neutral with regard to jurisdictional claims in published maps and institutional affiliations.
Ready to submit your research? Choose BMC and benefit from:

- fast, convenient online submission

- thorough peer review by experienced researchers in your field

- rapid publication on acceptance

- support for research data, including large and complex data types

- gold Open Access which fosters wider collaboration and increased citations

- maximum visibility for your research: over $100 \mathrm{M}$ website views per year

At BMC, research is always in progress.

Learn more biomedcentral.com/submissions 